\title{
WEALTH SHOCKS AND MPC HETEROGENEITY
}

\author{
Dimitris Christelis \\ Dimitris Georgarakos \\ Tullio Jappelli \\ Luigi Pistaferri \\ Maarten van Rooij \\ Working Paper 25999 \\ http://www.nber.org/papers/w25999
NATIONAL BUREAU OF ECONOMIC RESEARCH
1050 Massachusetts Avenue
Cambridge, MA 02138
June 2019

Christelis and Jappelli acknowledge financial support from the Italian Ministry of University and Research. The opinions expressed in the paper are those of the authors and do not necessarily reflect the views of the European Central Bank or of De Nederlandsche Bank. The views expressed herein are those of the authors and do not necessarily reflect the views of the National Bureau of Economic Research.

NBER working papers are circulated for discussion and comment purposes. They have not been peer-reviewed or been subject to the review by the NBER Board of Directors that accompanies official NBER publications.

(C) 2019 by Dimitris Christelis, Dimitris Georgarakos, Tullio Jappelli, Luigi Pistaferri, and Maarten van Rooij. All rights reserved. Short sections of text, not to exceed two paragraphs, may be quoted without explicit permission provided that full credit, including $(\odot$ notice, is given to the source. 
Wealth Shocks and MPC Heterogeneity

Dimitris Christelis, Dimitris Georgarakos, Tullio Jappelli, Luigi Pistaferri, and Maarten van

Rooij

NBER Working Paper No. 25999

June 2019

JEL No. D12,D14,E21

\section{ABSTRACT}

We use the responses of a representative sample of Dutch households to survey questions that ask how much their consumption would change in response to unexpected, permanent, positive or negative shocks to their home value. The average MPC is in the $2.1-4.7 \%$ range, in line with econometric estimates that use housing wealth and consumption realizations. However, our analysis uncovers significant sample heterogeneity, with over $90 \%$ of the sample reporting no consumption adjustment to positive or negative wealth shocks. The relation between the MPC from wealth shocks and cash-on-hand is negative, consistent with models with precautionary saving and liquidity constraints.

Dimitris Christelis

CSEF, University of Naples Federico II

Via Cintia, Monte S. Angelo

I-80126 Napoli (NA)

ITALY

and CSEF and CFS

dimitris.christelis@gmail.com

Dimitris Georgarakos

European Central Bank

Sonnemannstrasse 20 (Main Building)

60314 Frankfurt am Main

Germany

dimitris.georgarakos@ecb.int

Tullio Jappelli

Department of Economics

University of Naples Federico II

Via Cinzia 45

80126 Napoli, Italy

tullio.jappelli@unina.it
Luigi Pistaferri

Department of Economics

579 Serra Mall

Stanford University

Stanford, CA 94305-6072

and NBER

pista@stanford.edu

Maarten van Rooij

Dutch Central Bank

P. O. Box 98

1000 AB Amsterdam

The Netherlands

M.C.J.van.Rooij@DNB.NL 


\section{Introduction}

Housing is by far the most important asset most households own. Hence, the considerable volatility in house prices that many economies have recently experienced should have important implications for household spending. Notably, such responses in spending are likely heterogeneous across households and might differ between housing booms and busts.

Recent literature uses direct survey questions to elicit information about the consumption responses to scenarios involving positive and negative transitory income shocks (see, e.g., Christelis et al., 2019; Fuster et al., 2018). The approach is useful, as it provides household-specific estimates of the marginal propensity to consume (MPC) out of possible income changes. This allows associating MPCs with observables such as household resources, and comparing MPC responses of each household to different income shocks.

The present paper builds on this literature by estimating the impact of housing wealth shocks on households' expenditures. It makes three contributions. First, it takes advantage of the first (to the best of our knowledge) population-representative household survey providing consumption responses to alternative scenarios of idiosyncratic housing wealth shocks. Most of the literature so far has focused on the consumption effect of transitory income shocks and ignored wealth shocks. ${ }^{1}$ Housing not only represents the largest asset in household portfolios, but it is also illiquid and infrequently traded, and has both a consumption and an investment component. Thus, it is instructive to directly measure homeowners' consumption response to possible shocks to the value of their own house by explicitly asking about it. This can be useful, as it may, for example, help estimating the consumer spending drop due to a housing bust, an important policy exercise in light of the recent Great Recession.

\footnotetext{
${ }^{1}$ See Shapiro and Slemrod (1995; 2003); Jappelli and Pistaferri (2014); Graziani et al. (2016); Christelis et al. (2019a); Fuster et al. (2018).
} 
The second contribution regards the analysis of consumption responses to both positive and negative housing price shocks. As is the case with income shocks, it is important to investigate whether consumption responds asymmetrically to positive versus negative wealth shocks, as this asymmetry can have important implications about economic measures affecting house values (such as changes in the maximum allowed LTV ratio or property taxes).

Finally, the paper relates household heterogeneity in responses to a housing wealth shock to cash-on-hand, LTV ratio, age and other demographic variables, and examines whether these associations are consistent with existing models of consumption behavior.

We design a special module for a representative survey of Dutch households. The module includes questions on how respondents would change their consumption in response to an unexpected and permanent increase or decrease in their housing wealth corresponding to $10 \%$ of their house value. The survey shows that among homeowners the average MPC for positive shocks is $4.7 \%$, and $2.1 \%$ for negative shocks. These values are broadly in line with econometric estimates that use actual housing wealth and consumption data. However, our approach uncovers significant heterogeneity in MPC responses, as over $90 \%$ of homeowners report no reaction to either positive or negative shocks. For those who do react, an important question is how they finance the change in consumption, given that housing wealth is illiquid and indivisible. We find that reducing savings or using current income (in the case of a positive shock), or increasing saving (in the case of a negative shock) are the typical strategies followed by households.

In line with predictions of models with precautionary saving and liquidity constraints, we find a negative association between MPC and cash-on-hand. This is supported both by descriptive and by more formal regression analyses. We also examine whether households 
with different levels of indebtedness differ in their consumption response to housing wealth shocks. We find evidence that homeowners with high LTV ratios are particularly responsive to negative shocks. This is, as we shall discuss, consistent with the institutional environment

of the Netherlands, where underwater households are limited in their residential mobility choices and may face difficulties in getting additional credit.

The paper is organized as follows. Section 2 discusses the economic motivation and empirical evidence on the microeconomic estimates of the MPC out of wealth shocks. Section 3 describes the data and discusses advantages and limitations of the questions used in our survey to elicit the MPC out of wealth shocks. Section 4 discusses the descriptive analysis and the regression results relating the MPC to household socio-economic characteristics, along with some robustness checks. Section 5 concludes.

\section{Motivation and micro evidence}

Most literature estimating the consumption effect of a change in house prices relies on two implicit assumptions. First, consumers don't anticipate these wealth shocks. Second, current house prices are the best predictors of future ones; hence, consumers view any change in them as highly persistent.

Under these assumptions, the life-cycle permanent income model suggests that unexpected and permanent changes in housing wealth affect the consumption of homeowners by an amount equivalent to the annuity value of the shock. In addition to this wealth effect, a change in house prices can affect consumption through a liquidity effect, since housing wealth can be used as collateral. A drop in house prices reduces the ability to borrow, and increases the need for precautionary saving due to a reduced future ability to borrow (needed if, e.g., there is a negative future income shock). Both effects should reduce current consumption. 
Conversely, a positive shock on housing wealth attenuates liquidity constraints and the need for precautionary saving, stimulating consumption.

Note that there is a possible asymmetry between the effect of positive and negative wealth shocks. In the case of a negative shock, households with low cash-on-hand are more likely to reduce consumption than those with high cash-on-hand, given that the latter can draw on accumulated savings. Moreover, a drop in the house value should make it more difficult to borrow to smooth consumption using the house as collateral, thus aggravating the liquidity problem of those with low cash-on-hand. One should therefore expect a negative correlation between cash-on-hand and the MPC from a negative wealth shock.

In the case of a positive shock, however, consumers with high cash-on-hand can increase consumption by drawing on existing savings, while cash-poor consumers will be able to increase consumption only by borrowing using the appreciated house as collateral or by selling the house outright to lock-in their capital gain. In other words, the positive wealth shock likely alleviates borrowing constraints of cash-poor households. This should in turn favor pent-up consumption, as it can enable these households to increase their spending by an amount large enough to match what they would have spent under no liquidity constraints. Hence, the relation between MPC and cash-on-hand from positive wealth shocks is ambiguous, and depends on whether the positive shock allows households with low cash-onhand to borrow or sell the house.

From an empirical point of view, there is considerable disagreement over the magnitude of the wealth effect on consumption. There are also important differences between wealth shocks arising from changes in real estate value (which may be hard to monetize due to the illiquidity and indivisibility of the asset) and those arising from changes in the values of financial asset prices (which are more easily converted into cash). 
Many empirical studies that estimate the wealth effect rely on aggregate measures of house price changes (at national, regional, or county level), ignoring that house price risk has a significant idiosyncratic component, and that house price changes affect differently owners and renters. Studies using micro data find a wealth effect on consumption in the $1-4 \%$ range, and larger for financial wealth than real estate wealth shocks. ${ }^{2}$ When trying to estimate the wealth effect, applied research should address the issue that movements in house and stock prices are likely to be correlated with other economic events that may have an impact on income expectations. They should also distinguish carefully between anticipated and unanticipated changes in wealth, see Jappelli and Pistaferri $(2011 ; 2017)$ for a survey of the literature.

The two studies that are most closely related to the present one distinguish between three characteristics of wealth changes: predictability, persistence, and sign. Christelis et al. (2015) examine the effects of the recent crises in the US housing market and stock market on household spending, using micro data from the 2009 Internet survey of the Health and Retirement Study. They focus on negative and exogenous wealth changes, and find that the MPCs with respect to housing wealth and financial wealth losses are $1 \%$ and $3.3 \%$, respectively. They also find, in line with standard models of intertemporal choice, that consumption responds more strongly to permanent shocks than to shocks perceived as transitory.

Paiella and Pistaferri (2017) use the Italian Survey of Household Income and Wealth which contains data on subjective interest rate expectations to isolate exogenous changes in wealth (due only to asset price shocks) from anticipated changes (due to, for example, planned portfolio rebalancing). They estimate an overall wealth effect of about 3 cents per

\footnotetext{
${ }^{2}$ Ji et al. (2019) and Zhang (2019) use Dutch micro data to study the wealth effect on consumption.
} 
(unexpected) euro increase in wealth, primarily driven by changes in housing prices. Contrary to the predictions from the theory, they find that the consumption response to anticipated changes in wealth is also large and significant, of the same magnitude as the response to unanticipated changes. They also find evidence that the MPC from negative wealth shocks is larger than that from positive shocks, consistent with the presence of liquidity constraints.

One limitation of these studies is that the estimated MPC is an average of individual responses, and hence there is an implicit assumption that the wealth effect is the same across individuals. However, the MPC can be heterogeneous for several reasons, ranging from access to credit, differences in portfolio composition and liquidity, presence of a bequest motive, etc. In this paper we address this and other shortcomings of the literature by using direct survey questions on consumption responses to scenarios involving a $10 \%$ increase or decrease in one's home value. We are thus able to elicit an individual-specific MPC out of positive and negative wealth shocks, which can then be compared with aggregate estimates, and related to household resources, indebtedness and demographic variables. Of course, the credibility of our estimates relies on the quality of the survey and on the assumption that reactions to shock scenarios are correlated with actual behavior.

Our research design builds on the contributions by Shapiro and Slemrod (1995, 2003) who pioneered the use of subjective expectations to elicit qualitative responses to income shocks. Jappelli and Pistaferri (2014) refined the approach, considering quantitative responses to income shock scenarios, and providing quantitative estimates of the MPC from income shocks. In some recent contributions, Christelis et al. (2019) and Fuster et al. (2018) distinguish between positive and negative income shocks of different size. More generally, the paper fits in the literature using subjective measures of expectations in macroeconomics (for a survey, see Manski, 2017). 


\section{The data}

We use data from the CentER Internet panel, a project sponsored by the Dutch National Bank and maintained by CentERdata at Tilburg University. The baseline survey, known as the DNB Household Survey (DHS), is conducted once a year via the Internet and collects detailed information on a range of demographics and asset holdings for a representative sample of Dutch-speaking households in the Netherlands. ${ }^{3}$ In addition to the baseline survey, households may be asked, during the year, to participate in special purpose surveys.

To compare our analysis with previous literature, we first use our sample to replicate a typical regression estimating the MPC out of wealth shocks. For this purpose, we regress the growth rate of consumption on the growth rate of own home value in the last 12 months and quartiles of lagged cash-on-hand. ${ }^{4}$ The estimated coefficient (assumed to be the same for all households) is 0.17 with a standard error of 0.08 . Evaluated at the sample mean (median) of the ratio of home value to consumption, the implied MPC out of house price changes is $1.3 \%$ $(1 \%)$. These values are at the low-end of the range of MPC estimates obtained with macro and micro data for the U.S; for example, Aladangady (2017) estimates an MPC of $4.7 \%$ (see also Contreras and Nichols, 2010, for a comprehensive survey of the literature).

Based on these results, researchers may conclude that, on average, the MPC out of housing wealth shocks is about $1.3 \%$. As we show below, the average of individual MPCs from the direct survey questions is indeed similar. However, eliciting individual-specific MPCs out of wealth shocks has a number of advantages. First, we can test whether responses differ across households. Second, we can relate individual responses to cash-on-hand and other variables. Finally, we can distinguish between positive and negative shocks and test for

\footnotetext{
3 To ensure representativeness of the CentER panel, households selected to participate are provided with an Internet connection if they fail to have one.

${ }^{4}$ We recover the lagged value of cash-on-hand from the 2017 baseline DHS survey.
} 
asymmetric responses. To these purposes, we designed a special module that included questions aimed at measuring the MPC from housing wealth changes. We focus on housing, as it is the largest component of wealth for most households. Moreover, direct survey questions do not easily distinguish changes in financial wealth due to market prices from changes due to active saving. ${ }^{5}$

Besides the possibility to design questions in a population representative survey, there are additional reasons that make the Netherlands a suitable country for our analysis. First, about two-thirds of the adult population are homeowners and thus can more easily conceptualize scenarios of appreciation or depreciation in housing values.6 Furthermore, homeowners likely have fairly accurate knowledge about changes in their own house value.

Every year, municipalities assess the value of all houses falling under their property tax jurisdiction. Subsequently, municipalities send a notice of the assessed value to the homeowner for calculating the property tax. Importantly, this administrative value is updated every year based on housing transactions in the same area, giving most weight to nearby transactions. ${ }^{7}$ Additionally, households must report the assessed home value in their income tax form in order to calculate the imputed rent tax.

We administered the survey in September 2018 to all adult members of the CentER Internet panel. The survey first asks homeowners to provide an estimate of the current value of their house. It then asks them to report how they would change their consumption of durable and non-durable goods in the next 12 months in response to an unexpected change in

\footnotetext{
${ }^{5}$ Household financial portfolios are also quite heterogeneous, implying that a change in stock prices might affect considerably stockholders, but leave non-stockholders indifferent. Moreover, the same stock market portfolio may itself being differently diversified across households.

${ }^{6}$ This is partly due to the large volatility in house prices of the last decade: a housing bust in 2008-13 (when house prices declined by more than $20 \%$ ) was followed by a (still ongoing) housing boom.

7 Likewise, mortgagors are typically aware of their outstanding mortgage amount, not only due to bank statements but also by having to report the outstanding mortgage amount in their tax declaration.
} 
the value of their house. The question explicitly refers to a one-off, permanent increase (or decrease) in this value. Given the significant heterogeneity of the home value (due to geography, type of unit, and other idiosyncratic factors), we present respondents with wealth changes (expressed in euro) that correspond to $10 \%$ of their (self-assessed) home value. By tailoring the shock to household-specific home values, we avoid biasing responses by the size of the shock. ${ }^{8}$ Moreover, framing the question in a realistic context should increase the reliability of the consumption response. Finally, as the consumers provide a consumption change in euro, we can readily calculate an MPC estimate.

In more detail, we used the following question to elicit consumption responses to a positive wealth shock:

Suppose that the value of your house increases unexpectedly by YYY euro and that this increase in value of your house is permanent (that is, it lasts forever). In the next 12 months, how would you use this increase in the value of your house? (You can add a euro amount to item 1, item 2, or both).

1. Purchase non-durable goods and services (food, clothes, travel, vacation, entertainment, cosmetics, etc.) that you otherwise would not have purchased, namely an amount of XXX euro;

2. Purchase durable goods (cars, home improvement, furniture, jewelry, etc.) that you otherwise would not have purchased or that you would have purchased later, namely an amount of XXX euro;

3. Would not spend more on durable and non-durable goods and services than you otherwise would do.

4. I don't know.

The question for a negative wealth shock has been phrased symmetrically:

Imagine that the value of your house declines unexpectedly by YYY euro and that this reduction in value of your house is permanent (that is, it lasts forever). In the next 12 months, how would you react to this decrease in the value of your house?

1. Reduce spending on non-durable goods and services (food, clothes, travel, vacation, entertainment, cosmetics, etc.), namely an amount of XXX euro;

\footnotetext{
${ }^{8}$ Presenting, instead, respondents with a fixed euro change in wealth would imply a very large (small) shock for households with relatively low (high) house value.
} 
2. Cancel or postpone for later the purchase of durable goods (cars, home improvement, furniture, jewelry, etc.) that you otherwise would have purchased, namely an amount of XXX euro;

3. Would not spend less on durable and non-durable goods and services than you otherwise would do.

4. I don't know.

An advantage of our survey is that the same respondent replies to the questions on positive and negative shocks. To minimize framing problems, we randomly split the homeowner sample into two, and ask the first (second) group the positive (negative) shock question. Two weeks later, we ask the first group the negative shock question and vice versa.

In addition, we ask follow up questions to people reporting that they would adjust consumption in response to a positive or negative shock. This allows distinguishing between the various possible channels through which housing wealth shocks might affect consumption. ${ }^{9}$ Although the questions ask about consumption of non-durables and durables separately, for most of the analysis we combine the two answers into a single one.

The survey is a cross-section of 1,264 homeowners. It also collects information on a number of background characteristics (demographics, consumption, income, house value, financial wealth and indebtedness) that are useful for our analysis.

Several features of the survey questions are noteworthy. First, consumers report by how much they would increase or cut spending "in the next 12 months". A specific timeframe is important because it allows us to rule out that differences in the MPC arise from differences in the timing of planned spending. Of course, different adjustments in subsequent years

\footnotetext{
${ }^{9}$ In the case of a positive shock, respondents are asked to indicate how they would finance the reported increase in spending by choosing at least one of the following options: (a) drawing from savings or using current income; (b) selling the house, to cash in the capital gain; (c) drawing funds from a (mortgage or home equity) loan, using the house as collateral; (d) other means. In case of a negative shock, respondents are asked to indicate how they would use the money that they subtract from spending by choosing at least one of the following options: (a) add to savings; (b) invest in home improvements; (c) pay-off some of their debts; (d) other uses.
} 
cannot be ruled out. ${ }^{10}$ In principle, it would be useful to ask similar questions with other time horizons (e.g., how would consumption change in the second or later years after the shock) but this would considerably increase the questionnaire complexity.

Second, the questions provide quantitative metrics for the proposed scenarios, as opposed to questions eliciting qualitative information ("mostly save/ mostly spend") on how people spend a windfall, such as tax rebates. Although business cycle effects can never be ruled out, the period in which the survey was administered (September 2018) was a "normal" one, with GDP growing steadily at about $2.5 \%$ on an annual basis. Furthermore, as discussed below, our results are not affected by respondents' expectations or uncertainty about future house prices.

Given that in the Netherlands the cadastral value of the house is used for tax purposes, the housing shock scenarios also imply a tax change. Typically, the implied change in tax burden is small (in the order of about 100 euro per year), and hence it is unlikely to change behavior much relative to a case without tax implications. ${ }^{11}$ Hence, in our MPC calculations we assume that households ignore tax changes when responding.

Finally, note that a $10 \%$ permanent price change in the home value is non-trivial. In our sample, the mean (median) home value, among homeowners, is about 306,000 euro $(250,000$ euro). Our questions hence maximize the chance of observing a consumption response, as, due to possible adjustment costs, such a response is more likely to be observed when shocks are large. Indeed, it is possible that previous work has been unable to tightly estimate the MPC out of wealth shocks precisely because most shocks are small.

\footnotetext{
${ }^{10}$ Carroll et al. (2011) show that the long-term effect of housing losses on consumption could be larger than the short-term one.

${ }^{11}$ The amount is calculated using the median reported house value $(250,000$ euro) and the average rates on three real estate-related taxes (i.e., the municipality tax, the flood management, and the tax on imputed rents).
} 


\section{Empirical results}

\subsection{Descriptive analysis}

Table 1 reports descriptive statistics on the respondents with non-missing data for consumption changes due to positive and negative wealth shocks. Other statistics refer to the whole sample. The fraction of households reporting that they would increase consumption in response to a positive shock is $8.4 \%$, while the fraction reporting that they would reduce consumption in response to a negative shock is $9.4 \%$.

One reason why most respondents report no consumption response may be that a home price change affects in the same direction also the value of housing services consumption (i.e., imputed rent). Hence, they may think that the shock has not materially changed their intertemporal budget constraint, which would imply no change in non-imputed rent spending (which is what they are asked about in the survey). On the other hand, when the shock is positive, liquidity-constrained households could still choose to increase their spending to approach their desired non-constrained spending. Another reason for consumption inertia could be adjustment costs affecting durables. Finally, the illiquidity of the house could make it difficult to translate a capital gain into actual spending through borrowing or selling.

Using information on the house price change, one can compute the MPC for each homeowner for both positive and negative shocks. The sample averages of these MPCs are 4.7\% for positive shocks, and $2.1 \%$ for negative shocks. As discussed in Section 2, these MPC estimates are in line with existing ones derived from microeconomic and aggregate data. Nevertheless, they hide a vast heterogeneity of responses, with the majority of homeowners reporting that they would not react to house price changes, and a minority reporting both an extensive margin and a substantial intensive margin response. 
This reported MPC heterogeneity implies that for those who adjust consumption, the adjustment is considerable (their mean MPC is $56 \%$ for positive shocks, $21 \%$ for negative ones), even when we exclude those reporting unit MPC ( $34 \%$ and $14 \%$, respectively). Furthermore, most of the adjustment refers to durable goods that people plan to buy in case of positive shocks, or postpone purchasing in case of negative shocks.

Financial market frictions (for example, inability to access products like home equity loans) may induce asymmetries in the consumption response to positive and negative shocks. As already discussed, when households cannot borrow to increase their consumption and have little liquid wealth, they will not respond to house price increases. In contrast, they may still reduce consumption when a negative permanent wealth shock occurs. This implies that in principle one should expect the MPC from negative shocks to be larger than the MPC from positive shocks.

In practice, a statistical test for the equality of the two sample estimates reveals that one cannot reject the hypothesis that the proportion of respondents who would react to the wealth shock is the same for positive and negative shocks at the 5\% significance level. Looking at the magnitude of the response, while the sample estimate of the MPC from positive shocks exceeds that of negative shocks at the $1 \%$ confidence level, the difference becomes statistically insignificant once we drop observations for which the MPC is equal to 1 . Given the prevalence of zeros, we do not put too much confidence in such differences.

It is interesting to shed light on the mechanism through which unanticipated changes in housing wealth might increase consumption (e.g., take-up of additional mortgage debt). The survey contains follow up questions helping to distinguish between the various channels through which wealth effects might affect consumption. Of those reporting a positive consumption change, the majority $(65 \%)$ report that they would draw from their savings or 
use current income; $26 \%$ that they would top-up their mortgage, using their house as collateral; and only $20 \%$ that they would sell the house to cash the increase in home value (note that the survey allows for multiple answers, so the fractions do not sum to 1). Of those reporting that they would reduce consumption in response to a negative shock, $55 \%$ mentions that they would increase savings; $51 \%$ that they would pay off some of their debts; and $21 \%$ that they would use the money that is not spent on consumption to invest in home improvements.

The upper-left panel of Figure 1 shows the relation between log cash-on-hand (grouped into 20 equally sized bins) and the MPC out of positive shocks. We define cash-on-hand as the sum of household net income and financial wealth, net of consumer debt. An additional reason for adopting this definition is that households likely face high transaction costs from selling illiquid assets. ${ }^{12}$

The figure suggests a negative association between the MPC from positive shocks and cash-on-hand. While below median cash-on-hand the MPC is between 5 and $10 \%$, in the top percentiles it is close to zero, with almost no household adjusting consumption in response to the shock. Instead, looking at the top right panel, we find no clear pattern between the MPC from negative shocks and cash-on-hand.

The two other panels of Figure 1 refer to the distribution of MPC with respect to age, again grouped in 20 equally sized bins. For positive shocks, the correlation between age and MPC is positive, so that moving from the youngest to the oldest cohorts, the MPC increases from about 2 to $6 \%$. Again, for negative shocks we find essentially no relation between age and the MPC.

\footnotetext{
12 Therefore, low cash-on-hand households in our data include both those who have low net worth as well as those who are "wealthy hand-to-mouth", as defined by Kaplan and Violante (2014). Households of the latter type might have a large amount of illiquid assets (such as a house) but low levels of (liquid) financial assets.
} 


\subsection{Regression results}

Table 2 reports average marginal effects from probit models for the probability of making a consumption adjustment following positive and negative shocks equal to $10 \%$ of the home value. The specification in column (1) includes quartiles of cash-on-hand, as well as age, gender, family size, and dummies for high school and college education.

The probability of reporting a positive MPC declines quite significantly with cash-onhand, particularly at low levels of cash-on-hand. A move from the first quartile (the excluded category) to the third quartile of the cash-on-hand distribution is associated with a reduction of the probability of 3.9 percentage points, while a move to the fourth quartile reduces the probability by 10 percentage points. One explanation for the negative correlation between the MPC and cash-on-hand is that low cash-on-hand households are much more likely to sell the house after the positive shock (26\%) compared to those with cash-on-hand above the median $(10 \%)$. The negative correlation also suggests that credit markets are an important channel linking wealth shocks to consumption. Indeed, $32 \%$ of households with cash-on-hand below the median report that they would top up the mortgage after the positive shock, against $20 \%$ among those with cash-on-hand above the median.

Next, we check whether indebtedness affects the probability of increasing consumption (column 2). To this end, we use a dummy for households with a loan-to-value ratio (LTV) greater than $100 \% .{ }^{13}$ In fact, a $100 \%$ LTV is an important focal value for several reasons. First, in the Netherlands, applications for new mortgage debt are subject to a legal LTV cap of $100 \%$; many first-time homebuyers take out mortgages at or close to this capped value. Second, when households with high mortgage debt go underwater (due to declining house

\footnotetext{
13 To keep the LTV dummy predetermined, we drop few observations for which the LTV would have been higher (lower) than $100 \%$ in the case of negative (positive) shock scenario.
} 
prices), the cost of their debt increases when moving house or refinancing the mortgage. This is partly because the tax code does not allow mortgage interest rate deductions for the part of the mortgage loan exceeding the home value, and partly because mortgage interest rates on loans with an LTV higher than $100 \%$ have a surcharge. Moreover, higher mortgage payments reduce access to consumer credit.

Accounting for cash-on-hand, we do not find a significant association between LTV and the probability of reporting a consumption adjustment due to a positive shock. Columns 3 and 4 of Table 2 report the counterpart specifications for negative shocks. The MPC is again higher in the lower quartiles of cash-on-hand, showing that a move from the first to the third quartile of cash-on-hand increases the probability of a negative consumption adjustment by 7.0 percentage points ( 9.5 percentage points for a move to the fourth quartile). Given that a high LTV ratio denotes a high debt burden and thus a likely reduced ability to borrow more, it is not surprising that a high LTV reduces spending and that its effect is large and precisely estimated. In particular, we find that, in case of a negative shock, the probability of a consumption adjustment is 10.0 percentage points higher for highly indebted households.

We also estimate tobit regressions modeling the response of the MPC (which is censored at 0 and 1) to the two shocks, controlling for the socio-economic characteristics used above. In Table 3 we report the corresponding average marginal effects, conditional on the MPC being uncensored. Results are similar to those discussed for the probit estimates, suggesting that a similar set of factors contributes to both the intensive and extensive margin response of consumption to the two shocks. 


\subsection{Robustness checks}

Cash-on-hand is defined as current net household income plus net financial wealth. In additional regressions we check whether income and cash-on-hand have a different effect on the probability of making a consumption adjustment and on the MPC from wealth shocks. For this purpose, we use separate dummies for household net income and net financial wealth quartiles. Arguably, the consumption response to house price shocks might depend on the size of the shock itself, which by construction is proportional to the value of the house. Thus, in additional specifications, we also check whether the house value matters by controlling for housing wealth quartiles. The results suggest that the main driver of MPC is net financial wealth. Net income plays essentially no role, as the income quartile dummies are never statistically significant. Coefficients of the dummies for real assets are also mostly insignificant. These additional results are reported in the online Appendix, Tables A1 and A2.

Responses to the survey questions may be sensitive to the omission of variables reflecting individuals' general optimism or understanding of the survey questions or expectations and uncertainty about future housing prices. In view of this, we exploit the richness of our data and add to our baseline specifications indicators of the above factors.

First, we construct an indicator of optimism by taking the difference between subjective life expectancy (i.e., self-reported probability to survive upon age 65,80 or 90 , depending on the current age) and objective life expectancy (by gender and age) from official mortality tables. ${ }^{14}$ Second, since responses to our questions may be affected by financial sophistication, we control explicitly for respondents' financial literacy. ${ }^{15}$ Further, we check if expectations

\footnotetext{
${ }^{14}$ Puri and Robinson (2007) use a similar measure of optimism.

15 We proxy financial literacy by the number of correct answers out of the three basic questions measuring financial knowledge developed by Lusardi and Mitchell (2011).
} 
about future house prices affect the MPC, relying on a special set of questions that elicit, for each respondent, the first and second moments of the expected distribution of house prices. ${ }^{16}$

We find that our baseline estimates are insensitive to proxies for optimism, financial sophistication as well as expectations about future house prices and underlying uncertainty. In particular, the fact that respondents with different confidence about future house prices do not report, on average, different MPCs is consistent with the circumstances of the wealth shock questions, which refer to a $10 \%$ permanent increase or decrease in the home value (i.e., they do not involve any uncertainty).

We also check whether the MPC is related to bequest motives by constructing a variable that takes into account both the probability of making a bequest as well as the planned amount. ${ }^{17}$ We find that the coefficient of planned bequests (standardized by total cash-onhand) is negative, but statistically insignificant.

We also find that results are unaffected if we control for a dummy denoting planning to move. Further, results are similar if we replace cash-on-hand quartile dummies with log cashon-hand or the deciles (or ventiles) of the cash-on-hand distribution.

\section{Summary}

We use the responses of a representative sample of Dutch households to survey questions that ask how much their consumption would change in response to unexpected,

\footnotetext{
${ }^{16}$ Respondents report the minimum and maximum values in the following question: "Imagine you own an apartment worth $€ 100,000$ in the neighborhood you currently live in. What do you think will be the value of this apartment in 12 months, if you decide to sell it?" Using a simple triangular distribution, we calculate the mean and variance for each respondent. Guiso et al. (2002) first used this method to elicit individual-specific expectations and uncertainty about future income.

${ }_{17}$ We ask households to report the probabilities that they will leave an inheritance of: (i) $€ 10,000$ or more; (ii) $€ 100,000$ or more; and (iii) $€ 500,000$ or more. Based on reported probabilities to these questions we deduce a measure of planned bequest for each respondent.
} 
permanent shocks (positive or negative) to their house value. The average MPC is in the 2.1$4.7 \%$ range, in line with econometric estimates that use wealth and consumption realizations. Importantly, the survey questions elicit in a simple and effective way respondentspecific MPCs, and uncover significant sample heterogeneity. In particular, more than $90 \%$ of the sample does not respond to positive or negative housing wealth shocks. The few households who do, however, report significant consumption adjustments. The relation between the MPC from wealth shocks and cash-on-hand is negative, consistent with models with precautionary saving and liquidity constraints. In a related vein, homeowners that are underwater reduce consumption significantly when hit by a negative housing wealth shock. 


\section{References}

Aladangady, A. (2017), "Housing wealth and consumption: evidence from geographically linked microdata", American Economic Review 107, 3415-3446.

Bunn, P., Le Roux, J., Reinold, K. and Surico (2018), “The consumption response to positive and negative income shocks", Journal of Monetary Economics 96, 1-15.

Campbell, J., Cocco, J. (2007), "How do house prices affect consumption? Evidence from micro data", Journal of Monetary Economics 54, 591-621.

Carroll, C., Slacalek, J., Otsuka, M. (2011), "How large are housing and financial wealth effects? A new approach”, Journal of Money, Credit and Banking 43, 55-79.

Case, K. E., J. M., Quigley, R. J., Shiller (2013), "Wealth effects revisited: 1975-2012”, NBER Working Paper 18667.

Christelis, D., Georgarakos, D., Jappelli, T. (2015), "Wealth shocks, unemployment shocks and consumption in the wake of the Great Recession", Journal of Monetary Economics $72,21-41$.

Christelis, D., Georgarakos, D., Jappelli, T., Pistaferri L., van Rooij, M. (2019), “Asymmetric consumption effects of transitory income shocks", The Economic Journal (forthcoming).

Contreras, J., Nichols J. (2010), "Consumption responses to permanent and transitory shocks to house appreciation", Federal Reserve Board Finance and Economics Discussion Papers 2010-2032.

Disney, R., Gathergood, J., Henley, A. (2010), "House price shocks, negative equity and household consumption in the United Kingdom", Journal of the European Economic Association 8, 1179-1207.

Fuster, A., Kaplan, G., Zafar, B. (2018), "What would you do with \$500? Spending responses to gains, losses, news and loans", National Bureau of Economic Research, Working Paper No. 24386.

Graziani, G., van der Klaauw, W., Zafar, B. (2016) "Workers' Spending Response to the 2011 Payroll Tax Cuts", American Economic Journal: Economic Policy 8(4), 124-59

Guiso, L. Jappelli, T., Pistaferri, L. (2002) "An empirical analysis of earnings and employment risk", Journal of Business and Economic Statistics 20(2), 241-253.

Jappelli, T., Pistaferri, L. (2011), "The consumption response to income changes", Annual Review of Economics 2, 479-506.

Jappelli, T., Pistaferri, L. (2014), "Fiscal policy and MPC heterogeneity", American Economic Journal: Macroeconomics 6, 107-36.

Jappelli, T., Pistaferri, L. (2017), The Economics of Consumption. Oxford: Oxford University Press. 
Ji, K. Teulings, R., Wouterse, B. (2019), "Disentangling the effect of household debt on consumption", CPB Discussion Paper.

Hryshko, D., Luengo-Prado, M., Sorensen, B. (2010), "House prices and risk sharing", Journal of Monetary Economics 57, 975-987.

Ludwig, A., Sløk, T. (2004), "The relationship between stock prices, house prices, and consumption in OECD countries", The B.E. Journal of Macroeconomics 4, 1-28.

Lusardi, A., Mitchell, O. (2011), "Financial literacy around the world: An overview," Journal of Pension Economics and Finance 10, 497-508.

Manski, C. F. (2017), "Survey of measurement of probabilistic macroeconomic expectations: progress and promise", NBER Working Paper 13907.

Kaplan G., Violante, G.L. (2014), “A model of the consumption response to fiscal stimulus payments”, Econometrica 82, 1199-1239.

Paiella, M., Pistaferri, L. (2017), "Decomposing the wealth effect on consumption", The Review of Economics and Statistics 99, 710-721.

Puri, M., and D. Robinson (2007), "Optimism and economic choice,” Journal of Financial Economics 86, 71-99.

Shapiro, M.D., Slemrod, J. (1995), “Consumer response to the timing of income: evidence from a change in tax withholding", American Economic Review 85, 274-283.

Shapiro, M.D., Slemrod, J. (2003), "Did the 2001 tax rebate stimulate spending? Evidence from taxpayer surveys", in J.M. Poterba, ed., Tax Policy and the Economy 17, 83-109. Cambridge: MIT Press.

Zhang, L. (2019), "Do house prices matter for household consumption? Evidence from Dutch administrative data", CPB Discussion Paper. 
Table 1

Sample statistics

\begin{tabular}{|c|c|c|c|c|c|}
\hline & Mean & S.D. & Median & $95^{\text {th }} p c t$ & $N$ \\
\hline Fraction reporting positive $\Delta \mathrm{C}$ from positive $\Delta \mathrm{W}$ & 0.084 & 0.278 & 0.000 & 1.000 & 1,069 \\
\hline Fraction reporting negative $\Delta \mathrm{C}$ from negative $\Delta \mathrm{W}$ & 0.094 & 0.293 & 0.000 & 1.000 & 974 \\
\hline MPC out of positive $\Delta \mathrm{W}$ & 0.047 & 0.190 & 0.000 & 0.412 & 1,069 \\
\hline MPC out of negative $\Delta \mathrm{W}$ & 0.021 & 0.116 & 0.000 & 0.068 & 974 \\
\hline Age & 52.5 & 15.3 & 53.0 & 77.0 & 1,264 \\
\hline Female & 0.434 & 0.496 & 0.000 & 1.000 & 1,264 \\
\hline Family size & 2.341 & 1.183 & 2.000 & 5.000 & 1,264 \\
\hline High school & 0.353 & 0.478 & 0.000 & 1.000 & 1,263 \\
\hline College & 0.409 & 0.492 & 0.000 & 1.000 & 1,263 \\
\hline Cash-on-hand & 79,314 & 170,269 & 32,375 & 303,900 & 1,136 \\
\hline LTV $>100 \%$ & 0.045 & 0.208 & 0.000 & 0.000 & 1,043 \\
\hline
\end{tabular}

Note. Cash-on-hand is expressed in thousand euro. 
Table 2

Probit regressions for the determinants of the probability of positive MPC due to housing wealth shocks

\begin{tabular}{lllll}
\hline & \multicolumn{3}{l}{ Nositive wealth shock } & \multicolumn{2}{l}{ Negative wealth shock } \\
\hline Age & 0.001 & 0.001 & -0.001 & -0.000 \\
& $(0.001)$ & $(0.001)^{*}$ & $(0.001)$ & $(0.001)$ \\
Female & 0.002 & 0.008 & -0.016 & -0.016 \\
& $(0.018)$ & $(0.017)$ & $(0.020)$ & $(0.020)$ \\
Family size & -0.013 & -0.004 & -0.021 & -0.030 \\
& $(0.009)$ & $(0.008)$ & $(0.010)^{* *}$ & $(0.011)^{* * *}$ \\
High school & -0.022 & -0.031 & -0.046 & -0.060 \\
& $(0.023)$ & $(0.022)$ & $(0.029)$ & $(0.029)^{* *}$ \\
College & -0.029 & -0.035 & 0.003 & -0.004 \\
& $(0.022)$ & $(0.022)$ & $(0.026)$ & $(0.026)$ \\
II cash-on-hand quartile & -0.038 & -0.033 & -0.041 & -0.045 \\
& $(0.023)^{*}$ & $(0.023)$ & $(0.025)$ & $(0.026)^{*}$ \\
III cash-on-hand quartile & -0.039 & -0.034 & -0.070 & -0.058 \\
& $(0.023)^{*}$ & $(0.023)$ & $(0.027)^{* *}$ & $(0.028)^{* *}$ \\
IV cash-on-hand quartile & -0.100 & -0.082 & -0.095 & -0.079 \\
& $(0.029)^{* * *}$ & $(0.028)^{* * *}$ & $(0.030)^{* * *}$ & $(0.030)^{* * *}$ \\
LTV $>100 \%$ & & 0.059 & & 0.100 \\
& & $(0.040)$ & & $(0.033)^{* * *}$ \\
& & & & 833 \\
\hline N & 980 & 923 & 906 &
\end{tabular}

Note. Average marginal effects from probit estimates (robust standard errors clustered by household in parentheses). LTV $>100 \%$ is a dummy equal to one if the LTV exceeds $100 \%$. Stars indicate significance at the 1,5 and 10 percent levels, respectively. 
Table 3

Tobit regressions for the determinants of the MPC due to housing wealth shocks

\begin{tabular}{lllll}
\hline & \multicolumn{2}{l}{ Positive wealth shock } & \multicolumn{2}{l}{ Negative wealth shock } \\
\hline Age & 0.001 & 0.001 & -0.000 & -0.000 \\
Female & $(0.000)$ & $(0.000)^{* *}$ & $(0.000)$ & $(0.000)$ \\
& 0.000 & 0.006 & -0.006 & -0.005 \\
Family size & $(0.012)$ & $(0.011)$ & $(0.007)$ & $(0.006)$ \\
& -0.010 & -0.003 & -0.007 & -0.009 \\
High school & $(0.006)^{*}$ & $(0.005)$ & $(0.004)^{*}$ & $(0.004)^{* *}$ \\
& -0.013 & -0.021 & -0.009 & -0.012 \\
College & $(0.015)$ & $(0.014)$ & $(0.009)$ & $(0.008)$ \\
& -0.020 & -0.024 & 0.005 & 0.002 \\
II cash-on-hand quartile & $(0.015)$ & $(0.014)^{*}$ & $(0.008)$ & $(0.008)$ \\
& -0.029 & -0.023 & -0.009 & -0.010 \\
III cash-on-hand quartile & $(0.016)^{*}$ & $(0.015)$ & $(0.008)$ & $(0.008)$ \\
& -0.029 & -0.024 & -0.018 & -0.014 \\
IV cash-on-hand quartile & $(0.015)^{*}$ & $(0.015)$ & $(0.009)^{* *}$ & $(0.008)$ \\
& -0.069 & -0.054 & -0.030 & -0.024 \\
LTV $>100 \%$ & $(0.020)^{* * *}$ & $(0.018)^{* * *}$ & $(0.011)^{* * *}$ & $(0.010)^{* *}$ \\
& & 0.040 & & 0.025 \\
& & $(0.026)$ & & $(0.010)^{* *}$ \\
N & & & & 833 \\
\hline
\end{tabular}

Note. Average marginal effects from tobit estimates, censored at 0 and 1 (robust standard errors clustered by household in parentheses). LTV $>100 \%$ is a dummy equal to one if the LTV exceeds $100 \%$. Stars indicate significance at the 1,5 and 10 percent levels, respectively. 
Figure 1

The relation between the MPC, age and cash-on-hand
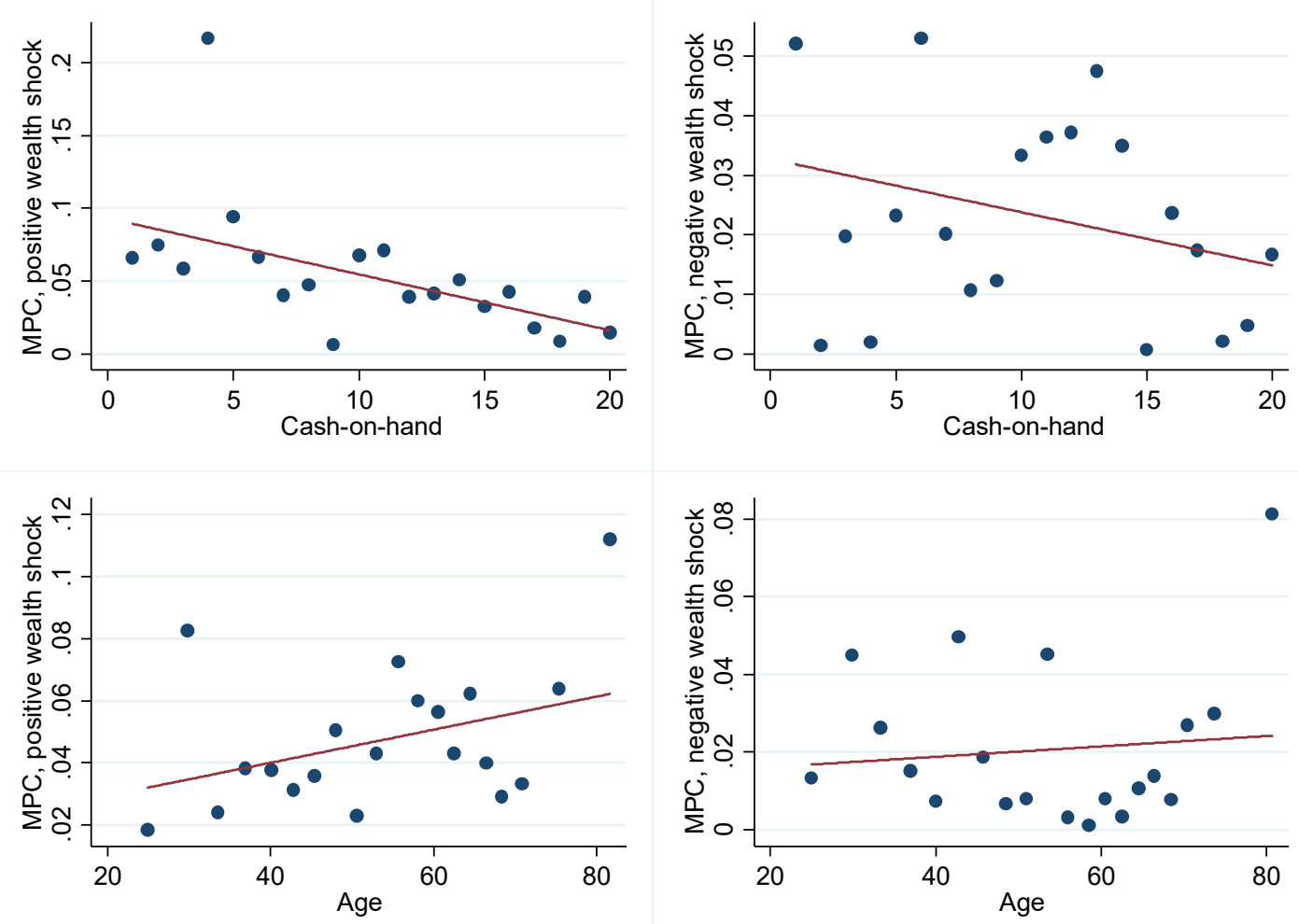


\section{Internet Appendix}

Table A1

Probit regressions for the determinants of the probability of positive MPC due to housing wealth shocks

\begin{tabular}{|c|c|c|c|c|c|c|}
\hline \multirow[b]{2}{*}{ Age } & \multicolumn{3}{|c|}{ Positive wealth shock } & \multicolumn{3}{|c|}{ Negative wealth shock } \\
\hline & $\begin{array}{c}0.001 \\
(0.001)\end{array}$ & $\begin{array}{c}0.001 \\
(0.001)^{*}\end{array}$ & $\begin{array}{c}0.001 \\
(0.001)\end{array}$ & $\begin{array}{l}-0.001 \\
(0.001)\end{array}$ & $\begin{array}{l}-0.000 \\
(0.001)\end{array}$ & $\begin{array}{l}-0.001 \\
(0.001)\end{array}$ \\
\hline Female & $\begin{array}{c}0.001 \\
(0.018)\end{array}$ & $\begin{array}{c}0.006 \\
(0.017)\end{array}$ & $\begin{array}{c}0.000 \\
(0.018)\end{array}$ & $\begin{array}{l}-0.018 \\
(0.020)\end{array}$ & $\begin{array}{l}-0.017 \\
(0.020)\end{array}$ & $\begin{array}{l}-0.018 \\
(0.020)\end{array}$ \\
\hline Family size & $\begin{array}{l}-0.010 \\
(0.009)\end{array}$ & $\begin{array}{c}0.001 \\
(0.008)\end{array}$ & $\begin{array}{l}-0.008 \\
(0.009)\end{array}$ & $\begin{array}{c}-0.019 \\
(0.011)^{*}\end{array}$ & $\begin{array}{c}-0.031 \\
(0.012)^{* *}\end{array}$ & $\begin{array}{c}-0.020 \\
(0.011)^{*}\end{array}$ \\
\hline High school & $\begin{array}{l}-0.019 \\
(0.023)\end{array}$ & $\begin{array}{l}-0.026 \\
(0.022)\end{array}$ & $\begin{array}{l}-0.019 \\
(0.023)\end{array}$ & $\begin{array}{l}-0.041 \\
(0.029)\end{array}$ & $\begin{array}{c}-0.057 \\
(0.029)^{* *}\end{array}$ & $\begin{array}{l}-0.041 \\
(0.028)\end{array}$ \\
\hline College & $\begin{array}{l}-0.024 \\
(0.023)\end{array}$ & $\begin{array}{l}-0.029 \\
(0.023)\end{array}$ & $\begin{array}{l}-0.024 \\
(0.023)\end{array}$ & $\begin{array}{c}0.008 \\
(0.027)\end{array}$ & $\begin{array}{c}-0.002 \\
(0.026)\end{array}$ & $\begin{array}{c}0.007 \\
(0.027)\end{array}$ \\
\hline II net fin wealth qrt & $\begin{array}{l}-0.036 \\
(0.022)\end{array}$ & $\begin{array}{l}-0.030 \\
(0.023)\end{array}$ & $\begin{array}{l}-0.029 \\
(0.022)\end{array}$ & $\begin{array}{c}-0.040 \\
(0.024)^{*}\end{array}$ & $\begin{array}{c}-0.046 \\
(0.025)^{*}\end{array}$ & $\begin{array}{c}-0.040 \\
(0.024)^{*}\end{array}$ \\
\hline III net fin wealth qrt & $\begin{array}{l}-0.036 \\
(0.025)\end{array}$ & $\begin{array}{l}-0.032 \\
(0.025)\end{array}$ & $\begin{array}{l}-0.029 \\
(0.025)\end{array}$ & $\begin{array}{c}-0.063 \\
(0.029)^{* *}\end{array}$ & $\begin{array}{c}-0.055 \\
(0.029)^{*}\end{array}$ & $\begin{array}{c}-0.063 \\
(0.029)^{* *}\end{array}$ \\
\hline IV net fin wealth qrt & $\begin{array}{c}-0.089 \\
(0.028)^{* * *}\end{array}$ & $\begin{array}{c}-0.070 \\
(0.027)^{* * *}\end{array}$ & $\begin{array}{c}-0.083 \\
(0.028)^{* * *}\end{array}$ & $\begin{array}{c}-0.102 \\
(0.030)^{* * *}\end{array}$ & $\begin{array}{c}-0.090 \\
(0.030)^{* * *}\end{array}$ & $\begin{array}{c}-0.102 \\
(0.030)^{* * *}\end{array}$ \\
\hline II net income qrt & $\begin{array}{l}-0.015 \\
(0.024)\end{array}$ & $\begin{array}{l}-0.016 \\
(0.023)\end{array}$ & $\begin{array}{c}-0.011 \\
(0.024)\end{array}$ & $\begin{array}{c}0.010 \\
(0.028)\end{array}$ & $\begin{array}{c}0.014 \\
(0.028)\end{array}$ & $\begin{array}{c}0.010 \\
(0.028)\end{array}$ \\
\hline III net income qrt & $\begin{array}{l}-0.018 \\
(0.026)\end{array}$ & $\begin{array}{l}-0.028 \\
(0.025)\end{array}$ & $\begin{array}{l}-0.013 \\
(0.026)\end{array}$ & $\begin{array}{l}-0.039 \\
(0.032)\end{array}$ & $\begin{array}{l}-0.026 \\
(0.032)\end{array}$ & $\begin{array}{l}-0.039 \\
(0.032)\end{array}$ \\
\hline IV net income qrt & $\begin{array}{l}-0.033 \\
(0.030)\end{array}$ & $\begin{array}{l}-0.041 \\
(0.030)\end{array}$ & $\begin{array}{l}-0.025 \\
(0.030)\end{array}$ & $\begin{array}{l}-0.003 \\
(0.033)\end{array}$ & $\begin{array}{c}0.015 \\
(0.033)\end{array}$ & $\begin{array}{l}-0.002 \\
(0.033)\end{array}$ \\
\hline $\mathrm{LTV}>100$ & & $\begin{array}{c}0.057 \\
(0.040)\end{array}$ & & & $\begin{array}{c}0.098 \\
(0.033)^{* * *}\end{array}$ & \\
\hline II house wealth qrt & & & $\begin{array}{l}-0.027 \\
(0.025)\end{array}$ & & & $\begin{array}{c}0.009 \\
(0.027)\end{array}$ \\
\hline III house wealth qrt & & & $\begin{array}{c}-0.048 \\
(0.024)^{* *}\end{array}$ & & & $\begin{array}{l}-0.002 \\
(0.027)\end{array}$ \\
\hline IV house wealth qrt & & & $\begin{array}{l}-0.009 \\
(0.025)\end{array}$ & & & $\begin{array}{c}0.004 \\
(0.028)\end{array}$ \\
\hline$N$ & 980 & 923 & 980 & 906 & 833 & 906 \\
\hline
\end{tabular}

Note. Average marginal effects from probit estimates (robust standard errors clustered by household in parentheses). LTV $>100 \%$ is a dummy equal to one if the LTV exceeds $100 \%$. Stars indicate significance at the 1,5 and 10 percent levels. 
Table A2

Tobit regressions for the determinants of the MPC due to housing wealth shocks

\begin{tabular}{|c|c|c|c|c|c|c|}
\hline \multirow[b]{2}{*}{ Age } & \multicolumn{3}{|c|}{ Positive wealth shock } & \multicolumn{3}{|c|}{ Negative wealth shock } \\
\hline & $\begin{array}{c}0.001 \\
(0.000)\end{array}$ & $\begin{array}{c}0.001 \\
(0.000)^{* *}\end{array}$ & $\begin{array}{c}0.001 \\
(0.000)\end{array}$ & $\begin{array}{l}-0.000 \\
(0.000)\end{array}$ & $\begin{array}{l}-0.000 \\
(0.000)\end{array}$ & $\begin{array}{l}-0.000 \\
(0.000)\end{array}$ \\
\hline Female & $\begin{array}{l}-0.001 \\
(0.012)\end{array}$ & $\begin{array}{c}0.004 \\
(0.011)\end{array}$ & $\begin{array}{l}-0.001 \\
(0.012)\end{array}$ & $\begin{array}{l}-0.007 \\
(0.007)\end{array}$ & $\begin{array}{l}-0.005 \\
(0.007)\end{array}$ & $\begin{array}{l}-0.007 \\
(0.007)\end{array}$ \\
\hline Family size & $\begin{array}{l}-0.007 \\
(0.006)\end{array}$ & $\begin{array}{l}-0.000 \\
(0.005)\end{array}$ & $\begin{array}{l}-0.006 \\
(0.006)\end{array}$ & $\begin{array}{l}-0.006 \\
(0.004)\end{array}$ & $\begin{array}{c}-0.009 \\
(0.004)^{* *}\end{array}$ & $\begin{array}{c}-0.006 \\
(0.004)^{*}\end{array}$ \\
\hline High school & $\begin{array}{l}-0.012 \\
(0.015)\end{array}$ & $\begin{array}{l}-0.018 \\
(0.014)\end{array}$ & $\begin{array}{l}-0.012 \\
(0.015)\end{array}$ & $\begin{array}{l}-0.007 \\
(0.009)\end{array}$ & $\begin{array}{c}-0.011 \\
(0.009)\end{array}$ & $\begin{array}{c}-0.007 \\
(0.009)\end{array}$ \\
\hline College & $\begin{array}{l}-0.017 \\
(0.015)\end{array}$ & $\begin{array}{l}-0.020 \\
(0.015)\end{array}$ & $\begin{array}{l}-0.016 \\
(0.015)\end{array}$ & $\begin{array}{c}0.007 \\
(0.009)\end{array}$ & $\begin{array}{c}0.003 \\
(0.008)\end{array}$ & $\begin{array}{c}0.007 \\
(0.009)\end{array}$ \\
\hline II net fin wealth qrt & $\begin{array}{c}-0.026 \\
(0.015)^{*}\end{array}$ & $\begin{array}{l}-0.020 \\
(0.015)\end{array}$ & $\begin{array}{l}-0.021 \\
(0.015)\end{array}$ & $\begin{array}{l}-0.007 \\
(0.008)\end{array}$ & $\begin{array}{l}-0.009 \\
(0.008)\end{array}$ & $\begin{array}{l}-0.007 \\
(0.008)\end{array}$ \\
\hline III net fin wealth qrt & $\begin{array}{c}-0.030 \\
(0.016)^{*}\end{array}$ & $\begin{array}{l}-0.025 \\
(0.016)\end{array}$ & $\begin{array}{c}-0.024 \\
(0.016)\end{array}$ & $\begin{array}{c}-0.017 \\
(0.009)^{*}\end{array}$ & $\begin{array}{l}-0.014 \\
(0.009)\end{array}$ & $\begin{array}{c}-0.017 \\
(0.009)^{*}\end{array}$ \\
\hline IV net fin wealth qrt & $\begin{array}{c}-0.061 \\
(0.019)^{* * *}\end{array}$ & $\begin{array}{c}-0.046 \\
(0.018)^{* *}\end{array}$ & $\begin{array}{c}-0.056 \\
(0.019)^{* * *}\end{array}$ & $\begin{array}{c}-0.032 \\
(0.011)^{* * *}\end{array}$ & $\begin{array}{c}-0.027 \\
(0.011)^{* *}\end{array}$ & $\begin{array}{c}-0.032 \\
(0.011)^{* * *}\end{array}$ \\
\hline II net income qrt & $\begin{array}{c}-0.014 \\
(0.016)\end{array}$ & $\begin{array}{l}-0.015 \\
(0.014)\end{array}$ & $\begin{array}{l}-0.011 \\
(0.015)\end{array}$ & $\begin{array}{c}0.002 \\
(0.009)\end{array}$ & $\begin{array}{c}0.003 \\
(0.009)\end{array}$ & $\begin{array}{c}0.002 \\
(0.009)\end{array}$ \\
\hline III net income qrt & $\begin{array}{l}-0.012 \\
(0.017)\end{array}$ & $\begin{array}{l}-0.017 \\
(0.016)\end{array}$ & $\begin{array}{l}-0.008 \\
(0.017)\end{array}$ & $\begin{array}{l}-0.013 \\
(0.011)\end{array}$ & $\begin{array}{l}-0.008 \\
(0.011)\end{array}$ & $\begin{array}{c}-0.013 \\
(0.011)\end{array}$ \\
\hline IV net income qrt & $\begin{array}{l}-0.023 \\
(0.020)\end{array}$ & $\begin{array}{l}-0.027 \\
(0.019)\end{array}$ & $\begin{array}{l}-0.015 \\
(0.020)\end{array}$ & $\begin{array}{l}-0.005 \\
(0.011)\end{array}$ & $\begin{array}{c}0.001 \\
(0.011)\end{array}$ & $\begin{array}{l}-0.004 \\
(0.011)\end{array}$ \\
\hline $\mathrm{LTV}>100$ & & $\begin{array}{c}0.039 \\
(0.025)\end{array}$ & & & $\begin{array}{c}0.025 \\
(0.010)^{* *}\end{array}$ & \\
\hline II house wealth qrt & & & $\begin{array}{l}-0.019 \\
(0.016)\end{array}$ & & & $\begin{array}{c}0.005 \\
(0.009)\end{array}$ \\
\hline III house wealth qrt & & & $\begin{array}{c}-0.036 \\
(0.016)^{* *}\end{array}$ & & & $\begin{array}{c}0.002 \\
(0.009)\end{array}$ \\
\hline IV house wealth qrt & & & $\begin{array}{l}-0.013 \\
(0.016)\end{array}$ & & & $\begin{array}{l}-0.002 \\
(0.009)\end{array}$ \\
\hline$N$ & 980 & 923 & 980 & 906 & 833 & 906 \\
\hline
\end{tabular}

Note. Average marginal effects from tobit estimates, censored at 0 and 1 (robust standard errors clustered by household in parentheses). LTV $>100 \%$ is a dummy equal to one if the LTV exceeds $100 \%$. Stars indicate significance at the 1,5 and 10 percent levels. 